\title{
Factor Influencing Job stress during Covid-19: Empirical Evidence from Bank Syariah Indonesia
}

\author{
Masyhuri $1^{*}$, Pardiman 2 , Siswanto ${ }^{3}$ \\ ${ }^{1}$ Student of Master Management, Postgraduate Program, Islamic University of Malang, Indonesia \\ ${ }^{2}$ Faculty of Economy and Business, Islamic University of Malang, Indonesia \\ ${ }^{3}$ Faculty of Economy, State Islamic University of Maulana Malik Ibrahim Malang, Indonesia \\ *Corresponding Author: 22002081017@unisma.ac.id
}

\begin{abstract}
Research on job stress on employees who carry out work from home is rarely studied, so this research is essential considering that Covid-19 impacts the Indonesian Islamic banking industry. This article aims to analyze work-family conflict mediated by an organizational commitment to job stress at Bank Syariah Indonesia employees. The sample was Bank Syariah Indonesia employees who were scattered in several areas in East Java as many as 197 respondents from various branch offices and units. Questionnaires are distributed via google form as direct data collection from respondents. Furthermore, the data were analyzed using structural equation modeling partial least square (SEM-PLS), which was then used to answer the research hypothesis. The results showed work-family conflict affects employee job stress. Work-family conflict affects organizational commitment, organizational commitment has a significant effect on job stress, and organizational commitment mediates work-family conflict on job stress. Implications for further research suggest comparing job stress during the pandemic and after the pandemic. The theoretical contribution of this research supports conflict theory and scarcity theory which says that stress in one role can limit an individual's ability to fulfill other roles, which will lead to work-family conflict.
\end{abstract}

Keywords: Covid-19; Job stress; Organizational commitment; Work-family conflict, work from home

\section{INTRODUCTION}

Covid 19 is a pandemic that started in early 2020 and is still not over. Various government policies have been implemented, such as large-scale social restrictions from 2020 to 2021, implementing ongoing community activities. The restrictions were done to break the chain of spreading the coronavirus. One of the policies in effect is work from home or work from home for all business sectors, the Islamic banking sector. Bank Syariah Indonesia, which results from a merger of three state-owned Islamic banks, namely Bank BRI Syariah, Bank BNI Syariah, and Bank Mandiri Syariah, was influential since February 1, 2021. Amid the increase recorded as of September 2020 showed assets of Rp 542.83 trillion (Wimboh, 2020). However, new challenges arise with the presence of covid-19. 
Work from home is a new phenomenon, especially in Indonesia, but all parties must do it for the common interest. Working from home has both positive and negative impacts. The positive impact is to help the government reduce the spread of the coronavirus, but the negative is the increasing frequency of conflicts that occur for employees who have to work from home. This conflict causes employees to feel stressed because it is challenging to balance work time and family time. The world economic forum's survey results stated that during the WFH period during the Covid-19 period, the working time was longer, more emails were sent, and shorting the meeting time (Yoshio, 2020). Conditions can make employees feel bored at work and confused in doing their jobs because of the directions given during shorter meetings.

A work-family conflict is a form of conflict between roles where there is a mismatch in several ways between the pressure at work and family (Isfianadewi and Noordyani 2020). Role conflict occurs due to an imbalance between the roles currently being played, such as the role of husband and employee. Several empirical studies suggest that workfamily conflicts can increase job stress (Lambert et al., 2017; Lee and Jang, 2017; Vickovic and Morrow, 2020). However, the results were different from those (Isfianadewi and Noordyani 2020), which proves there is no relationship between work-family conflict and job stress. This research is interesting because there are still inconsistencies in some of the results of previous studies, and there are still open gaps or gaps in research. Likewise, recommendations from (Horesh and Brown 2020) say that the area of traumatic stress should be addressed as it is a severe need that will arise now and in the future.

Furthermore, previous research results found that work-family conflict significantly affects organizational commitment (Vickovic and Morrow 2020; Yuwono et al. 2020). Organizational commitment describes a desire that each individual has with the aim of staying in the organization with any situation and condition, a strong intention to continue to work hard for the achievement of organizational goals, and always comply with the standards set by the company and the company's ideals which has been specified (Vickovic and Morrow, 2020). Commitments are formed independently and without any pressure or coercion from anyone. This commitment is still a savior for the company during the crisis it is experiencing. Because this commitment can reduce the stress experienced by employees

Apart from the inconsistencies of some of the previous studies' results, this study tries to fill in the limitations of the research owned by (Vickovic and Morrow 2020), who suggested testing work-family conflict mediated by an organizational commitment on job stress using structural equation modeling. Besides, very few researchers research work family conflict mediated by an organizational commitment on job stress at Islamic banking.

\section{HYPOTHESES DEVELOPMENT}

\section{Work-family conflict and job stress}

Conflict can occur because of an imbalance between roles in the family and roles in work. Two theories explain work-family conflict, namely conflict theory, which proposes that work and family domains are not compatible because of their different norms and responsibilities. The scarcity theory assumes that each human being has limited time, energy, and attention, and human devotion as an individual who can only give full attention to one role so that the other roles are slightly neglected (Hunsaker, 2020). Based on the two theories above, it can be concluded that stress in one role can limit an 
individual's ability to fulfill other roles (if the focus is on work, the family may be neglected, and vice versa), this condition will lead to work-family conflicts. Work-family conflict is closely related to job stress, so we assume that work-family conflict affects job stress.

Job stress is defined as a dangerous physical and emotional response if it occurs when job qualifications do not match the worker's abilities, resources, or needs (Armstrong, Atkin-Plunk, and Wells 2015). Therefore, there is a gap between ability and job qualification needs to make employees feel stressed. Job stress can be categorized into two things, namely stimulus. Stimulus is felt by employees who experience role conflicts, role ambiguity, excessive roles, and dangerous jobs. Meanwhile, employees' job stress is felt by employees from anxiety, depression, worry, emotional exhaustion, and other work-related pressures (Chen et al. 2019). Previous research has shown that work-family conflict directly affects job stress (Cao et al. 2020; Lee and Jang 2017; Rabenu, Tziner, and Sharoni 2017; Vickovic and Morrow 2020). Furthermore, based on empirical studies (Vickovic and Morrow 2020; Yuwono et al. 2020), work-family conflict significantly affects organizational commitment. So, the proposed hypothesis is:

$\mathrm{H}_{1}$ : Work-family conflict affect job stress

$\mathrm{H}_{2}$ : Work-family conflict affect organizational commitment

\section{Organizational commitment and job stress}

Organizational commitment describes a desire that each individual has with the aim of staying in the organization with any situation and condition, a strong intention to continue to work hard for the achievement of organizational goals, and always comply with the standards set by the company and the company's ideals which has been specified (Lambert et al. 2020). Organizational commitment is closely related to employee loyalty to an organization where they work. Sometimes employees also have job stress that needs to be managed. Therefore, organizational commitment is closely related to job stress. So, the hypothesis is put forward as follows:

$\mathrm{H}_{3}$ : There is a significant influence between organizational commitment to job stress $\mathrm{H}_{4}$ : Work-family conflict toward job stress through organizational commitment

Based on theoretical studies supported by several previous research results, a conceptual research framework can be prepared, as shown in Figure 1.

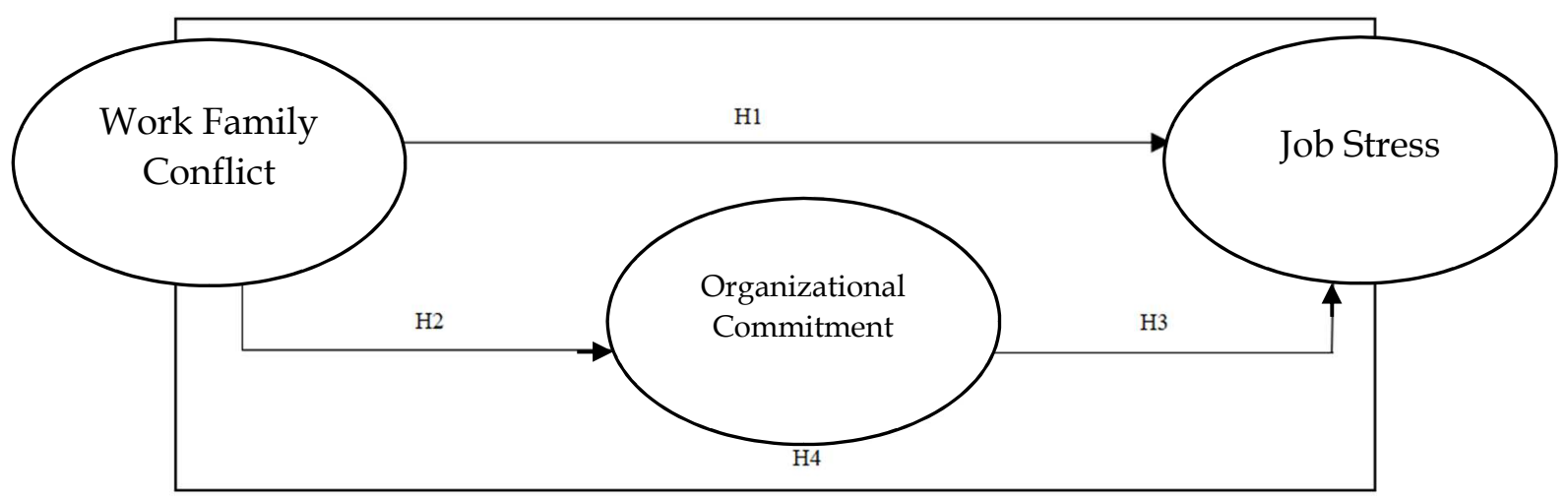

Figure 1. Research Concept Framework 


\section{METHOD, DATA, AND ANALYSIS}

\section{Method}

This research uses quantitative analysis with the structural equation modeling approach to partial least squares (SEM-PLS). Data were collected using a questionnaire on Indonesian Islamic bank employees. Bank Syariah Indonesia is the result of a merger of three state-owned Islamic banks, namely Bank BNI Syariah, Bank Syariah Mandiri, and Bank BRI Syariah, which is valid since February 1, 2021. The questionnaire was distributed via google form and managed to respond to 197 employees using a purposive sampling technique. Respondents are scattered in several areas in East Java, such as (Surabaya, Sumenep, Mojokerto, Lumajang, Malang), and employees who work from home. The sample is sufficient to represent the entire population of Indonesian Islamic banks in East Java. The number of samples obtained from calculations using the Slovin formula with a probability of 5\%. Questionnaires were distributed on February 1-25th. Data were analyzed using SmartPLs 3.0; there are two steps in data analysis, namely the algorithm used to test the data's quality, then bootstrapping is used to test the research hypothesis (Hair et al. 2015).

The work-family conflict variable is measured using a scale developed by (Vickovic and Morrow 2020) using 12 items. Furthermore, the organizational commitment variable uses (Lambert et al. 2020) scale's with five items. The job stress variable uses a scale of the development results (Mansour and Tremblay 2018) using eight items. Each item uses a 5point Likert scale from 1 (strongly disagree) to 5 (strongly agree). Furthermore, a variable measurement that uses the development of previous research and support by theory. Then, the pretest testing was carried out in the form of validity and reliability testing carried out on 30 respondents as a pretest. Based on the pilot test results, it can be seen that the items used in this study are valid and reliable. Therefore, in this study, there is no need to carry out the process of selecting invalid items because all items used are valid and reliable. For more details, the results of the pilot test as well as being used for actual research can be presented as following table 1 :

Table 1. The Development of Questionnaire

\begin{tabular}{|c|c|c|c|}
\hline Variable & Indicators & Item & Reference \\
\hline \multirow{10}{*}{$\begin{array}{l}\text { Work family } \\
\text { conflict }\end{array}$} & WFC1 & My job gives me enough time to be with my family & (Vickovic and \\
\hline & WFC2 & $\begin{array}{l}\text { When I'm not working I make time for family and } \\
\text { / or social }\end{array}$ & $\begin{array}{l}\text { Morrow } \\
\text { 2020) }\end{array}$ \\
\hline & WFC3 & $\begin{array}{l}\text { When I'm not working I make time for family and } \\
\text { / or social }\end{array}$ & \\
\hline & WFC4 & $\begin{array}{l}\text { My work schedule is stable enough to allow me to } \\
\text { plan with family and / or socially }\end{array}$ & \\
\hline & WFC5 & $\begin{array}{l}\text { I can count in family or social activities / events } \\
\text { outside of Work }\end{array}$ & \\
\hline & WFC6 & $\begin{array}{l}\text { With all the Work, sometimes I come home } \\
\text { stressed }\end{array}$ & \\
\hline & WFC7 & Because of this Work, I often get irritable at home & \\
\hline & WFC8 & My job had a bad impact on my domestic life & \\
\hline & WFC9 & $\begin{array}{l}\text { My family / friends don't like it when I'm busy } \\
\text { with Work }\end{array}$ & \\
\hline & WFC10 & $\begin{array}{l}\text { The behaviors I adopt at work help me become a } \\
\text { better friend }\end{array}$ & \\
\hline
\end{tabular}


Table 1. The Development of Questionnaire (Continues)

\begin{tabular}{|c|c|c|c|}
\hline Variable & Indicators & Item & Reference \\
\hline \multirow[t]{2}{*}{$\begin{array}{l}\text { Work family } \\
\text { conflict }\end{array}$} & WFC11 & $\begin{array}{l}\text { I sometimes have to be absent because of family / } \\
\text { social problems }\end{array}$ & \\
\hline & WFC12 & $\begin{array}{l}\text { Due to stress at home, I often get busy with family } \\
\text { matters at work }\end{array}$ & \\
\hline \multirow[t]{5}{*}{$\begin{array}{l}\text { Organizational } \\
\text { Commitment }\end{array}$} & KO1 & $\begin{array}{l}\text { I am very concerned about the future of the } \\
\text { company I work for }\end{array}$ & \multirow[t]{5}{*}{$\begin{array}{l}\text { (Lambert et } \\
\text { al. 2020) }\end{array}$} \\
\hline & $\mathrm{KO} 2$ & $\begin{array}{l}\text { I am proud to tell others that I work for this } \\
\text { company }\end{array}$ & \\
\hline & $\mathrm{KO} 3$ & $\begin{array}{l}\text { For me, achieving company targets is very } \\
\text { important }\end{array}$ & \\
\hline & $\mathrm{KO} 4$ & $\begin{array}{l}\text { I am willing to work harder than ever to help this } \\
\text { company move forward }\end{array}$ & \\
\hline & KO5 & To me, this is the best of all the companies & \\
\hline \multirow[t]{6}{*}{ Job Stress } & SK1 & I feel calm & \multirow{6}{*}{$\begin{array}{l}\text { (Mansour } \\
\text { and Tremblay } \\
\text { 2018) }\end{array}$} \\
\hline & SK2 & I feel rushed; I don't seem to have enough time & \\
\hline & SK3 & I feel busy, tormented, or worried & \\
\hline & SK4 & $\begin{array}{l}\text { I am confused; my mind is messed up; I lack } \\
\text { concentration; I can't focus }\end{array}$ & \\
\hline & SK5 & $\begin{array}{l}\text { I have difficulty controlling my reactions, } \\
\text { emotions, moods or gestures }\end{array}$ & \\
\hline & SK6 & I feel stressed & \\
\hline
\end{tabular}

\section{DATA AND ANALYSIS}

Based on the respondents' answers to the questionnaire in table 2, it was found that explaining that the work-family conflict variable got a minimum answer of 1 and a maximum of 5 with a mean value of 3.64 and a standard deviation of 0.62 . This means that the majority of respondents agree with the questionnaire items submitted regarding workfamily conflicts in their families.

Table 2. Statistic Descriptive

\begin{tabular}{lcccc}
\hline & Min & Max & Mean & SD \\
\hline Work Family Conflict & 1 & 5 & 3.64 & 0.62 \\
Organizational Commitment & 1 & 5 & 3.83 & 0.73 \\
Job Stress & 1 & 5 & 3.90 & 0.73 \\
\hline
\end{tabular}

Source: Processed Data 2021

Furthermore, on the organizational commitment variable, the answer was a minimum of 1 and a maximum of 5 with a mean value of 3.64 and a standard deviation of 0.73 . This means that the respondent agrees with the statement of the items in the questionnaire regarding the organizational commitment of the individual respondent. And the job stress variable gets a minimum answer of 1 and a maximum of 5 with a mean value of 3.64 and a standard deviation of 0.73 . This means that respondents agreed that they felt job stress during the Covid-19 pandemic, as evidenced by the respondents' answers who mostly agreed with the statements regarding job stress in the questionnaires that were distributed.

Respondents in this study were male as many as 103 people (52\%) and female as many as 94 people $(48 \%)$. This illustrates that the majority of respondents are male. 
Furthermore, there were 49 respondents aged 21-30 years (25\%), 31-40 years old 56 people $(28 \%), 41-50$ years old 61 people $(31 \%)$ while the rest were> 50 years 31 people $(16 \%)$. So it can be concluded that the sample is representative of various groups from adults to older adults. Furthermore, most respondents are currently married to as many as 116 people $(84 \%)$, while the remaining 31 people are unmarried $(16 \%)$. The number explains that the majority of respondents are married and have dependents at home. The education of respondents from senior high school was ten people (5\%), S1 as many as 167 people (85\%), while the remaining 20 people $(10 \%)$ were S2 graduates. The majority of respondents' employee status is permanent employees of 167 people $(85 \% 0$ while the rest are nonpermanent employees. The respondent's residence with their family is 176 people $(89 \%)$ while the rest live alone. For more details, see table 3.

Table 3. Characteristics of Respondents

\begin{tabular}{clccc}
\hline No. & Characteristics & Description & Frequency & $\%$ \\
\hline 1 & Sex & Male & 103 & $52 \%$ \\
& & Female & 94 & $48 \%$ \\
2 & \multirow{2}{*}{ Age } & $21-30$ year & 49 & $25 \%$ \\
& & $31-40$ year & 56 & $28 \%$ \\
& & $41-50$ year & 61 & $31 \%$ \\
\multirow{2}{*}{3} & \multirow{2}{*}{ Marital Status } & $>50$ year & 31 & $16 \%$ \\
& & Single & 31 & $16 \%$ \\
4 & \multirow{2}{*}{ Education } & Married & 166 & $84 \%$ \\
& & Senior High School & 10 & $5 \%$ \\
\multirow{2}{*}{5} & \multirow{2}{*}{ Employee status } & S1 & 167 & $85 \%$ \\
& & S2 & 20 & $10 \%$ \\
6 & \multirow{2}{*}{ Residence } & Permanent & 167 & $85 \%$ \\
& & Non-permanent & 30 & $15 \%$ \\
& & With Family & 176 & $89 \%$ \\
\hline
\end{tabular}

Source: Processed data 2021

\section{RESULTS}

\section{Measurement Model Analysis}

The measurement model includes (work-family conflict, organizational commitment, and job stress), each variable has a loading factor value greater than 0.70 (Hair et al. 2015), so it can be concluded that all constructs are valid. Furthermore, the reliability test can be seen in Table 4, which shows that the work-family conflict variable has a Cronbachs alpha value of 0.938 , organizational commitment of 0.895 , and job stress of $0.908>(0.70)$ well as the composite reliability value that is greater than 0.70 . So it can be concluded that the construct used in this study is reliable. The AVE values were 0.594, 0.673, and 0.687, respectively, which were more significant than 0.50 . This value shows the level of reliability of each variable. 
Table 4. Data Quality Testing

\begin{tabular}{|c|c|c|c|c|c|}
\hline Variables & Items & $\begin{array}{l}\text { Loading } \\
\text { Factor }\end{array}$ & $\begin{array}{c}\text { Cronbach } \\
\text { Alpha }\end{array}$ & $\begin{array}{l}\text { Composite } \\
\text { Reliability }\end{array}$ & AVE \\
\hline Work Family & WFC1 & 0.777 & 0.938 & 0.946 & 0.594 \\
\hline \multirow[t]{11}{*}{ Conflict } & WFC2 & 0.761 & & & \\
\hline & WFC3 & 0.750 & & & \\
\hline & WFC4 & 0.786 & & & \\
\hline & WFC5 & 0.802 & & & \\
\hline & WFC6 & 0.751 & & & \\
\hline & WFC7 & 0.758 & & & \\
\hline & WFC8 & 0.761 & & & \\
\hline & WFC9 & 0.775 & & & \\
\hline & WFC10 & 0.797 & & & \\
\hline & WFC11 & 0.780 & & & \\
\hline & WFC12 & 0.746 & & & \\
\hline Organizational & KO1 & 0.820 & 0.895 & 0.911 & 0.673 \\
\hline \multirow[t]{4}{*}{ Commitment } & $\mathrm{KO} 2$ & 0.738 & & & \\
\hline & KO3 & 0.803 & & & \\
\hline & $\mathrm{KO} 4$ & 0.876 & & & \\
\hline & KO5 & 0.856 & & & \\
\hline \multirow[t]{6}{*}{ Job Stress } & SK1 & 0.748 & 0.908 & 0.929 & 0.687 \\
\hline & SK2 & 0.825 & & & \\
\hline & SK3 & 0.856 & & & \\
\hline & SK4 & 0.846 & & & \\
\hline & SK5 & 0.827 & & & \\
\hline & SK6 & 0.864 & & & \\
\hline
\end{tabular}

Source: Processed data 2021

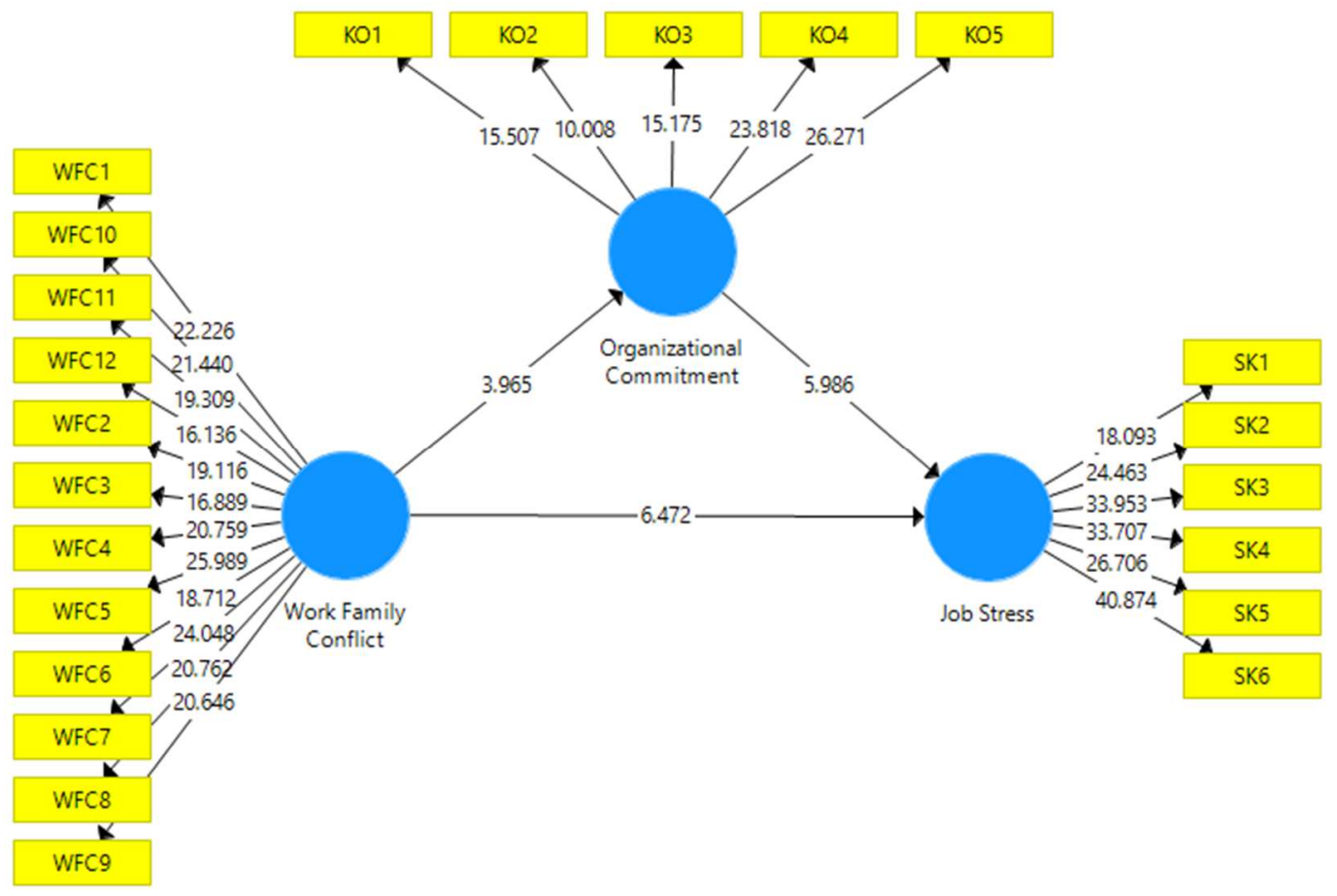

Figure 2. Results of structural equation modeling using Smartpls (Source: Smartpls research output, 2021) 
The structural model analysis in Figure 2 is used to test hypotheses with the bootstrapping method in the smartPLS 3.0 application. Specifically, to examine the effect of work-family conflict and job stress, organizational commitment is mediated. To test the hypothesis, we follow (Hair Jr et al. 2017) in testing the structural model analysis using several approaches. First, we examine relationship between work-family conflict toward job stress directly to test hypothesis 1 . Second, test work-family conflict on organizational commitment as a hypothesis 2 . Third, organizational test commitment to job stress as a hypothesis 3 . Fourth, organizational commitment is a mediating variable, and the overall test is conducted by including the variable of organizational commitment as a mediation between work-family conflict and job stress.

Table 5. Direct Testing

\begin{tabular}{|c|c|c|c|c|c|}
\hline & Path Analysis & $\begin{array}{c}\text { Sample } \\
\text { Mean }\end{array}$ & $\begin{array}{c}\mathrm{T}- \\
\text { Statistic }\end{array}$ & $\begin{array}{c}\text { T- } \\
\text { Table }\end{array}$ & Result \\
\hline $\mathrm{H}_{1}$ & $\mathrm{WFC} \rightarrow$ Job Stress & 0.436 & 6.218 & & Accepted \\
\hline $\mathrm{H}_{2}$ & $\begin{array}{l}\text { WFC } \rightarrow \text { Organizational } \\
\text { Commitment }\end{array}$ & 0.226 & 4.086 & 1.96 & Accepted \\
\hline $\mathrm{H}_{3}$ & $\begin{array}{l}\text { Organizational Commitment } \rightarrow \text { Job } \\
\text { Stress }\end{array}$ & -0.321 & 5.377 & & Accepted \\
\hline
\end{tabular}

Source: Processed Data 2021

Furthermore, in Table 5 and Table 6, the results of testing the research hypothesis can be seen. As expected, work-family conflict directly affects job stress $(t=6.218 p<0.05)$. Then the direct effect of work-family conflict on organizational commitment $(\mathrm{t}=4.086 \mathrm{p}<0.05)$, therefore, $\mathrm{H} 1$ and $\mathrm{H} 2$ are accepted. Furthermore, $\mathrm{H} 3$, namely the direct effect of organizational commitment on job stress $(t=5,377 \mathrm{p}<0.05)$, therefore the hypothesis is in accordance with what is proposed.

Table 6. Indirect Testing

\begin{tabular}{lc}
\hline \multicolumn{1}{c}{ Hypothesis } & Mediation \\
\hline Influence of Indirect Variables (T-Statistic) & Organizational Commitment \\
Work-Family Conflict and Job Stress & 3.875
\end{tabular}

Source: Processed Data 2021

In mediation testing the organizational commitment, variable mediates the results of testing the indirect relationship between work-family conflict toward job stress $(t=3.875$, $\mathrm{p}<0.05)$, then $\mathrm{H} 4$ is accepted.

\section{DISCUSSION}

Based on the results of descriptive statistics, it can be seen that the mean value of the respondent's answers regarding the existence of work-family conflict in the personal life of the respondents, most of whom agree with the statements presented in the questionnaire. Therefore this study proves that the work-family conflict that each individual employee has can affect the work stress you have at work. This result is corroborated by the results of this study prove that work-family conflict can significantly affect job stress. The positive coefficient value shows that more increasing work-family conflict at home caused higher 
employee job stress at Bank Syariah Indonesia in East Java. Work-family conflict is described as a balance between the role of husband or child in the family and the role of an employee in the workplace. Adequacy of time at home can significantly affect employee job stress. This condition illustrates employees who do work from home due to a government policy that requires them to work from home during the Covid-19 pandemic. The increasing frequency of online meetings can reduce time with family and the inability to attend social events in the neighborhood. The results of this study support the results of research from (Cao et al., 2020; Lee \& Jang, 2017; Liu et al., 2017; Rabenu et al., 2017; Vickovic \& Morrow, 2020) and, who agree that work-family conflict affects job stress. These results also support conflict theory and scarcity theory which explain that stress is one of the roles that can limit an individual's ability to fulfill other roles (if the focus is on work, it is likely that the family will be neglected, and vice versa), this condition will lead to workfamily conflict.

Furthermore, in descriptive statistics, the mean value of respondents regarding job stress answers is also shown, and it is concluded that the majority of respondents agree with the statements submitted in the questionnaire. This indicates that the majority of employees at Bank Syariah Indonesia have work stress during the Covid-19 pandemic period due to government policies regarding work from home. In line with this study, it also succeeded in finding that work-family conflict can affect employee organizational commitment. The positive sign on the coefficient value illustrates more increasing workfamily conflict causes higher organizational commitment to Bank Syariah Indonesia in East Java. Organizational commitment can be described by employee loyalty to a company, employees who are happy if the company's targets are achieved, and employees' willingness to work harder for the advancement of the company where they work. This study's results align with previous studies (Vickovic and Morrow 2020; Yuwono et al. 2020), which agree that work-family conflicts can affect organizational commitment.

Then the descriptive statistics show that the respondents' answers to the questionnaire regarding organizational commitment are in the high category because the majority of respondents agree that employees already have a good organizational commitment to the company. With this organizational commitment, employees are proven to be able to reduce the job stress they feel. This is also reinforced by the results of this study which found that organizational commitment has a significant influence on job stress. A negative sign on the coefficient value indicates that the higher the employee's organizational commitment can significantly reduce the employee's job stress. Job stress is described by a person's condition at work or in a state not working. The conditions can be reflected in the physical condition that is often dizzy, often unfocused, confused thoughts, and unable to control emotions. This condition, according to this study, can be reduced by high organizational commitment. The results of this study are in line with the hypothesis that has been proposed.

The research results above show organizational commitment able to mediate the relationship between work-family conflict toward job stress. This result illustrates that work-family conflict can have a more substantial influence on job stress mediated with organizational commitment. This study's results complement the results of research from (Morrow et al. 2019), who recommends further research to examine work-family conflict on job stress that is mediated by organizational commitment. 


\section{CONCLUSION, LIMITATIONS, AND SUGGESTIONS}

\section{Conclusion}

In general, work-family conflict can increase job stress, as well as organizational commitment. Furthermore, organizational commitment has a significant influence on job stress. Ever farther, organizational commitment mediates the relationship between workfamily conflict and job stress. The results illustrate that most of the employees at Bank Syariah Indonesia in East Java have work-family conflicts in their households. The perception is illustrated by the answers to respondents' questionnaires that show that they agree that they have problems in their homes related to the work from the home policy implemented during the period. This pandemic, then the respondents responded that the majority have a high organizational commitment. This is reflected in their answers, who try to work harder to advance the Indonesian Sharia Bank. Then the last answer was the respondent's answer regarding the job stress they experienced. They admitted that the work from home policy resulted in increased job stress. The conditions are because it is challenging to balance work time and time with family, considering the increasing frequency of online meetings and tasks that must be done more and more.

This research has practical implications that the management of Bank Syariah Indonesia can apply in East Java. The companies need to pay attention to the conditions of each employee, especially in work-family conflicts. This can be investigated directly by each employee's personnel department, through interviews and other instruments, so that employees can tell stories freely and without any pressure regarding conditions in their households due to policies regarding work from home during the Covid-19 pandemic. Furthermore, the personnel department can measure employees' performance before and after implementing work from home. If there is a decline, further investigation is needed.

This study proves that each employee at Bank Syariah Indonesia in East Java has a high commitment to the company where he works so that the management or leadership of Bank Syariah Indonesia is expected to maintain employee trust in the company and continue to provide the best facilities for employees because employees have tried their best for the progress of the company. Employees at Bank Syariah Indonesia in East Java are relatively high regarding job stress, so companies need to evaluate programs. The banks carried out such as the frequency of online meetings, additional tasks besides the primary duties of each employee because it is evident in this study that employees find it challenging to manage time between work and with family, besides that employee must balance between work and with family.

In addition, the theoretical contribution of this research is supported by conflict theory and scarcity theory which says that stress in one role can limit an individual's ability to fulfill other roles, this condition will lead to work-family conflict. In general, this study illustrates that employees at Bank Syariah Indonesia in East Java during the Covid-19 pandemic with the work from home system increased conflicts that occurred both in the family and at work, with conflicts that occurred could increase employee job stress. However, this can be anticipated because there is still a firm commitment from each employee to work. Simultaneously, this is a challenge for the company to keep employees having a strong commitment by providing adequate salaries according to job qualifications and providing bonuses for those who reach targets. 


\section{Limitation and suggestions}

This research has several limitations, such as it was only carried out during the Covid-19 pandemic, which may have different results in normal situations. Furthermore, the object of research is still limited to the province of East Java. The results of the research can be very different if it is carried out in other provinces or even the same. Furthermore, it is recommended for future research to compare job stress during the pandemic and after the pandemic and add research objects to the Indonesian Sharia Bank in other provinces like Sumatera Kalimantan, Jakarta. It is recommended to add other mediating variables to find out other factors that can affect job stress in the company.

\section{REFERENCES}

Armstrong, G. S., Atkin-Plunk, C. A., \& Wells, J. (2015). The relationship between workfamily conflict, correctional officer job stress, and job satisfaction. Criminal Justice and Behavior, 42(10), 1066-1082. https:// doi.org/10.1177/0093854815582221

Cao, J., Liu, C., Wu, G., Zhao, X., \& Jiang, Z. (2020). Work-Family Conflict and Job Outcomes for Construction Professionals: The Mediating Role of Affective Organizational Commitment. International Journal of Environmental Research and Public Health, 17(4), 1443. https://doi.org/10.3390/ijerph17041443

Chen, J., Li, J., Cao, B., Wang, F., Luo, L., \& Xu, J. (2020). effects of self-efficacy, coping, burnout, and social support between job stress and mental health among young Chinese nurses. Journal of Advanced Nursing, 76(1), 163-173. https://doi.org/10.1111/jan.14208

Hair, J., Celsi, M., Money, A., Samouel, P., \& Page, M. (2015). Business research methods. Armonk, NY: ME Sharpe.

Hair Jr, J. F., Sarstedt, M., Ringle, C. M., \& Gudergan, S. P. (2017). Advanced issues in partial least squares structural equation modeling. saGe publications.

Horesh, D., \& Brown, A. D. (2020). Traumatic stress in the age of COVID-19: A call to close critical gaps and adapt to new realities. Psychological Trauma: Theory, Research, Practice, and Policy, 12(4), 331. https://doi.org/10.1037/tra0000592

Hunsaker, W. D. (2020). Spiritual leadership and work-family conflict: Mediating effects of employee well-being. Personnel Review.

Isfianadewi, D., \& Noordyani, A. (2020). Implementation of Coping Strategy in WorkFamily Conflict on Job Stress and Job Satisfaction: Social Support as Moderation Variable. Review of Integrative Business and Economics Research, 9, 223-239.

Lambert, E. G., Qureshi, H., Frank, J., Keena, L. D., \& Hogan, N. L. (2017). The relationship of work-family conflict with job stress among Indian police officers: A research note. Police Practice and Research, 18(1), 37-48. https:/ / doi.org/10.1080/15614263.2016.1210010

Lambert, E. G., Keena, L. D., Leone, M., May, D., \& Haynes, S. H. (2020). The effects of distributive and procedural justice on job satisfaction and organizational commitment ofcorrectional staff. The Social Science Journal, 57(4), 405-416. https:// doi.org/10.1016/j.soscij.2019.02.002 
Lee, A., \& Jang, Y. (2017). The impact of work/ family conflict and workplace social support on mental distress in-home health workers. Home Health Care Management E Practice, 29(3), 176-182. https:// doi.org/10.1177/1084822317702883

Liu, J., Lambert, E. G., Jiang, S., \& Zhang, J. (2017). A research note on the association between work-family conflict and job stress among Chinese prison staff. Psychology, Crime \& Law, 23(7), 633-646. https:/ / doi.org/10.1080/1068316X.2017.1296148

Mansour, S., \& Tremblay, D.-G. (2016). Work-family conflict/family-work conflict, job stress, burnout and intention to leave in the hotel industry in Quebec (Canada): Moderating role of need for family-friendly practices as "resource passageways". The International Journal of Human Resource Management, 29(16), 2399-2430. https:// doi.org/10.1080/09585192.2016.1239216

Morrow, W. J., Vickovic, S. G., Dario, L. M., \& Shjarback, J. A. (2019). Examining a Ferguson effect on college students' motivation to become police officers. Journal of Criminal Justice Education, 30(4), 585-605. https:/ / doi.org/10.1080/10511253.2019.1619793

Mowday, R. T., Porter, L. W., \& Steers, R. (1982). Organizational linkages: The psychology of commitment, absenteeism, and turnover. San Diego, CA: Academic Press.

Rabenu, E., Tziner, A., \& Sharoni, G. (2017). The relationship between work-family conflict, stress, and work attitudes. International Journal of Manpower. https:// doi.org/10.1108/IJM-01-2014-0014

Vickovic, S. G., \& Morrow, W. J. (2020). Examining the influence of work-family conflict on job stress, job satisfaction, and organizational commitment among correctional officers. Criminal Justice Review, 45(1), 5-25. https:// doi.org/10.1177/0734016819863099

Yuwono, T., Novitasari, D., Sutardi, D., Mustofa, M., \& Asbari, M. (2020). Peran Organizational Commitment terhadap Hubungan Work-Family Conflict dan Kepuasan Kerja Karyawan Wanita di Kota Seribu Industri Tangerang. EduPsyCouns: Journal of Education, Psychology and Counseling, 2(1), 524-540.

Wimboh, S. (2020). Perbankan Di Kuasai Bank Konvensional, RI Perlu Bank Syariah Berskala Besar. [online] https://tirto.id/perbankan-dikuasai-konvensional-ri-perlubank-syariah-skala-besar-f4Sr, (Accessed 1 Januari 2021).

Yoshio, A. (2020) Survei: Work from Home Picu Jam Kerja Bertambah dan Kelelahan Mental , [online] https://katadata.co.id/ariemega/berita/5fa7cf815a0e8/surveiwork-from-home-picu-jam-kerja-bertambah-dan-kelelahan-mental. (Accessed 12 February 2021) 